\title{
GAME EDUKASI DUA DIMENSI PENGENALAN HEWAN BERDASARKAN CARA BERKEMBANGBIAKNYA
}

\author{
Ngakan Putu Darma Yasa ${ }^{1}$, Ni Kadek Nita Noviani Pande ${ }^{2}$ \\ ${ }^{12}$ STMIK STIKOM Indonesia Denpasar, Teknik Informatika, \\ ${ }^{1}$ darma.yasa@stiki-indonesia.ac.id
}

\begin{abstract}
Abstrak
Penelitian ini bertujuan untuk menghasilkan media belajar berupa game edukasi. Game edukasi ini dapat diisi konten pembelajaran yang diperlukan oleh anak sehingga mampu memberikan alternatif belajar baru. Tahapan yang dilalui dalam penelitian ini mulai dari mengumpulkan datadata dengan metode observasi, wawancara, dokumentasi dan kepustakaan. Perancangan game melalui beberapa proses tahapan, yaitu pra-produksi, produksi dan pasca-produksi. Game edukasi yang dirancang berisi materi pengenalan hewan berdasarkan cara berkembangbiaknya. Hewan yang ditampilkan dalam game adalah hewan yang sering ditemukan sehari-hari seperti ayam, kelinci dan gajah. Game edukasi yang dihasilkan berbasis desktop artinya hanya bisa dimainkan dalam komputer.
\end{abstract}

Kata kunci: Game Edukasi, Hewan, Cara Berkembangbiak

\begin{abstract}
This research aims to produce learning media in the form of educational games. This educational game can be filled with learning content needed by children so as to provide new learning alternatives. The stages in this research start from collecting data by observation method, interview, documentation and literature. Game design through several stages, namely preproduction, production and post-production. Educational games designed to contain animal recognition materials based on how to breed. Animals featured in the game are animals that are often found everyday such as chickens, rabbits and elephants. Desktop-based educational games mean they can only be played on a computer.
\end{abstract}

Keywords: Educational Games, Animals, How to Breed

\section{PENDAHULUAN}

Game saat ini adalah media digital yang banyak dimainkan dan dinikmati, baik oleh orang dewasa maupun anak-anak. Hal ini dikarenakan banyaknya developer yang mengembangkan game. Bermain adalah suatu kegiatan yang sangat menyenangkan, sehingga hal ini mampu memberikan rasa nyaman secara psikologis pada anak-anak. Dengan bermain game, anak memiliki kesempatan melakukan eksplorasi untuk memenuhi rasa ingin tahu yang ada dalam dirinya. Namun, saat ini permainan yang ada dalam komputer maupun video game terkadang tidak mampu mengasah kemampuan anak dalam memecahkan masalah. Hal itu disebabkan karena, cukup dengan menekan tombol saja pemain sudah mendapatkan jawaban yang benar. Video game juga sering membatasi interaksi antara anak dengan orang lain karena hanya fokus pada game saja (Suryana, 2016).

Menurut Henry (Henry, 2010) tampilan grafis dari sebuah game yang hampir menyerupai wujud aslinya membuat para gamer menjadi kecanduan. Beberapa game yang hadir juga semakin komplit dilihat dari alur permainannya dan banyak juga game yang mengandung konten kekerasan serta tidak sesuai untuk dikonsumsi oleh anak-anak usia dini. Beberapa dampak negatif yang 
diakibatkan oleh game bagi anak-anak yang sudah kecanduan adalah isolasi sosial dengan menutup diri karena bermain game seharian dan menimbulkan kekerasan yang diikuti dengan kata-kata kasar.

Namun, tidak semua game berpengaruh negatif terhadap anak. Game juga bisa digunakan ke arah yang positif dan bermanfaat dalam membantu proses belajarnya. Game tersebut adalah game edukasi. Game edukasi merupakan aplikasi digital yang didesain untuk memberikan pembelajaran kepada seseorang tentang materi tertentu. Game edukasi sangat bermanfaat dalam membantu proses belajar anak sambil bersantai. Game edukasi bisa digunakan sebagai alternatif dalam proses belajar agar tidak jenuh dan dapat dilakukan dalam suasana santai (Habibu Rahman, 2020). Materi belajar yang didesain dalam bentuk game, diharapkan bisa lebih menarik serta menyenangkan. Apalagi game dibuat dengan sistem leveling dan scoring, maka akan semakin memicu anakanak yang memainkannya untuk menyelesaikan setiap level yang ada dalam game dengan score tertinggi. Menurut Sudiarta dalam wawancara menerangkan bahwa, efektivitas game edukasi dalam proses pembelajaran sangat bagus dan mampu meningkatkan interest anak-anak yang memainkannya, karena game adalah sesuatu yang bergerak, bersuara, dan beranimasi.

Anik Vega Vitianingsih (Anik Vega Vitianingsih, 2016) dalam penelitiannya menerangkan bahwa game edukasi memiliki beberapa keunggulan jika dibandingkan dengan pembelajaran metode konvensional. Beberapa keunggulan tersebut adalah terdapat animasi yang mampu meningkatkan daya ingat sehingga anak bisa menyimpan materi pelajaran dalam kurun waktu yang lebih lama dibandingkan dengan pengajaran metode konvensional.

Pendidikan yang bisa dikemas dalam game edukasi dapat berupa materi pelajaran di sekolah salah satunya adalah pengenalan hewan. Penggolongan hewan sudah mulai diajarkan sejak kelas 3 sekolah dasar. Terdapat 3 penggolongan hewan yaitu berdasarkan makanannya, berdasarkan cara berkembangbiaknya dan berdasarkan tempat hidupnya. Dalam Game Edukasi Pengenalan Hewan yang dirancang penulis pada penelitian ini dibatasi pada topik berdasarkan cara berkembangbiaknya. Game edukasi ini didesain dengan memiliki tingkatan permainan sampai 3 level. Setiap level, pemain diajak untuk berpetualang di laut sambil mencari makan sampai muncul pertanyaan tentang hewan. Pemain juga disiapkan menu untuk belajar terlebih dahulu sebelum memulai permainan. Dengan mengkemas game berbasis desktop, anak-anak bisa melihat dengan tampilan yang lebih lebar sehingga mengurangi jarak antara mata dan layar.

Atas dasar penjelasan tersebut, penulis merancang sebuah game edukasi yang berjudul "Game Edukasi Dua Dimensi Pengenalan Hewan Berdasarkan Cara Berkembangbiaknya". Game Edukasi ini dititikberatkan pada sub materi pengenalan hewan berdasarkan cara berkembangbiaknya.

Untuk mendukung kebaruan dalam penelitian ini, penulis menggunakan beberapa literatur penelitian terdahulu, yaitu: "Game Edukasi Berbasis Android Sebagai Media Pembelajaran Untuk Anak Usia Dini" (Putra, 2016) oleh Dian Wahyu Putra sebagai penulis pertama membahas tentang perancangan game edukasi pengenalan binatang, pengenalan lagu anak, pengenalan alphabet dan mewarnai. Game yang diciptakan sudah berbasis android sehingga mudah untuk disitribusikan. Game ini terdapat banyak sub materi yang dikemas dan belum sesuai kurikulum yang berlaku.

Penelitian yang berjudul "Game Edukasi Mata Pelajaran Ilmu Pengetahuan Alam (IPA) Dan Ilmu Pengetahuan Sosial (IPS) Pada Sekolah Dasar Negeri Sooka I Punung Kabupaten Pacitan" (Sari, 2015) yang dilakukan oleh Putri Intan Sari sebagai penulis pertama membahas tentang perancangan game edukasi pengenalan Ilmu Pengetahuan Alam dan Ilmu Pengetahuan Sosial. Materi pembelajaran yang dikemas dalam Game ini disesuaikan dengan kurikulum yang dipakai oleh sekolah yang menjadi objek penelitian. Desain dalam game ini menggunakan jenis font yang terlalu kaku sehingga sulit untuk dibaca.

Penelitian yang berjudul "Pengembangan Game Edukasi Pengenalan Nama Hewan Dan Habitatnya Dalam 3 Bahasa Sebagai Media Pembelajaran Berbasis Multimedia" (Ridwan Arif Rahman, 2016) yang dilakukan oleh Ridwan Arif Rahman membahas tentang perancangan game 
edukasi mengenalkan hewan serta habitatnya. Game yang dihasilkan menggunakan 3 bahasa yang berbeda termasuk Bahasa Indonesia. Pemilihan jenis font yang digunakan terlalu banyak script, sehingga sulit untuk dibaca.

Keterkaitan penelitian terdahulu yang sudah dipaparkan di atas dengan penelitian yang dilakukan penulis sekarang adalah pembahasan yang mirip yaitu membahas tentang game edukasi. Kelebihan yang penulis ingin tambahkan dalam penelitian sekarang adalah adanya konsep petualangan dalam game edukasi yang dirancang. Dari penelitian terdahulu yang sudah dipaparkan, tidak ada yang menambahkan konsep petualangan dalam game yang dirancang. Pemilihan jenis huruf yang digunakan adalah huruf yang tidak terlalu formal seperti Century Gothic.

Game yang dirancang penulis ingin mengajak pemainnya seolah-olah bertualang sambil belajar. Petualangan dilakukan oleh seekor ikan Badut sambil memakan ikan kecil untuk menambah poin. Pemilihan karakter ikan Badut terinspirasi dari game Feeding Frenzy. Feeding Frenzy merupakan game petualangan yang dilakukan oleh karakter Ikan dengan memakan ikan-ikan kecil untuk mengumpulkan poin dan untuk menambah ukuran badan. Perbedaan antara Feeding Frenzy dengan game yang dirancang penulis adalah terdapatnya materi pembelajaran di dalamnya.

Desain tampilan awal pada game edukasi yang penulis rancang, menampilkan judul, nyawa, skor, desain background, dan tombol yang digunakan untuk mengontrol permainan. Pada tampilan awal, pemain dapat memilih tombol belajar terlebih dahulu agar bisa menjawab pertanyaan yang muncul pada tampilan level 1, level 2 dan level 3. Pemain juga bisa mempelajari cara memainkan game, mengetahui info dari perancang dan mengatur tampilan game. Tampilan menu awal game edukasi ini seperti gambar 1 dibawah.

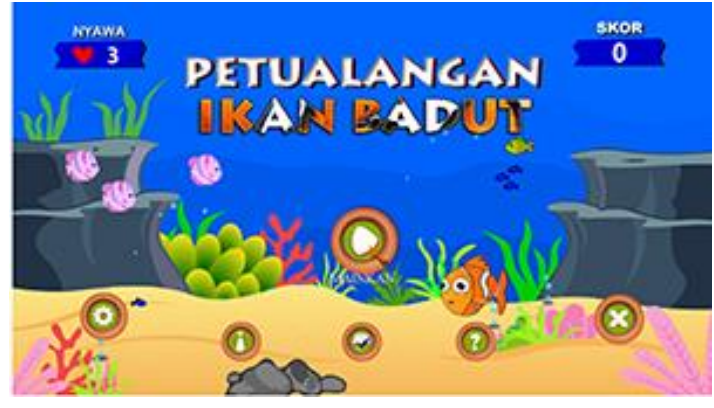

Gambar 1. Tampilan Awal Game Petualangan Ikan Badut

[Sumber: Darma Yasa, Ngakan 2020]

Selain menggunakan penelitian terdahulu sebagai referensi, penulis juga menggunakan beberapa buku teori yang berkaitan dengan perancangan Game Edukasi Pengenalan Hewan Berdasarkan Cara Berkembangbiaknya. Beberapa buku teori tersebut adalah teori tentang multimedia, teori warna, teori game edukasi dan penggolongan hewan.

Multimedia dapat diartikan bahwa informasi komputer dapat dipresentasikan melalui audio, video, dan animasi selain dari media tradisional. Multimedia adalah bidang yang berkaitan dengan integrasi teks, grafik, gambar diam atau bergerak yang didesain dan dikendalikan oleh komputer. Multimedia merupakan penggunaan teknologi komputer untuk mengolah dan menyajikan serta menggabungkan tipe file suara, teks, animasi, gambar, dan video menjadi sebuah informasi (Limbong, Toni \& Simarmata, 2020). Menurut Binanto (Binanto, 2010) multimedia terbagi menjadi 3, yaitu :

A. Multimedia interaktif

User bisa mengatur elemen-elemen multimedia yang akan ditampilkan atau dikirimkan.

B. Multimedia hiperaktif

memiliki struktur elemen-elemen multimedia yang terhubung langsung dengan user.

C. Multimedia linear

User sebagai penonton serta dapat menikmati hasil multimedia yang ditampilkan.

Berdasarkan penjelasan jenis multimedia tersebut, game edukasi pengenalan hewan termasuk ke dalam multimedia interaktif, karena pemainnya bisa mengatur 
dan mengontrol kapan elemen multimedia ingin ditampilkan. Elemen multimedia yang digunakan untuk melengkapi game edukasi ini adalah teks, gambar, suara, dan animasi. Dalam multimedia terdapat lima elemen dasar yaitu:

A. Teks adalah elemen yang berfungsi dalam menyampaikan informasi. Teks mempunyai banyak jenis dan bentuk yang mampu memberikan daya tarik dalam penyampaian informasi.

B. Gambar adalah elemen yang sering digunakan untuk menyampaikan informasi secara visual. Gambar dapat membantu menyampaikan informasi menjadi lebih berkesan dan menarik. Gambar yang digunakan dalam Game Edukasi Pengenalan Hewan ini adalah vektor. Kualitas vektor tidak bergantung pada resolusi komputer, jadi visualisasinya tetap bagus berapa pun resolusi komputer yang dipakai. Selain itu, grafis vektor juga tidak terlalu banyak memerlukan ruang penyimpanan.

C. Suara mampu membantu dalam penyampaian informasi dengan lebih efektif seperti menggunakan suara latar atau suara khusus yang berkaitan dengan materi. Suara digunakan untuk membantu pengguna dalam meningkatkan daya tarik terhadap suatu tayangan yang dipresentasikan. Audio yang digunakan dalam game ini adalah format MP3. Format MP3 memiliki kualitas suara yang bagus dan kapasistas media penyimpanannya juga tidak terlalu banyak.

D. Animasi dalam multimedia bisa membantu menjelaskan sebuah konsep secara detail dalam bentuk simulasi. Beberapa jenis animasi yang digunakan dalam game yaitu animasi frame by frame untuk menggerakkan ekor Ikan Badut, animasi vektor untuk keseluruhan asset game, dan animasi karakter untuk menganimasikan seluruh karakter yang terdapat dalam game.

Warna merupakan sifat cahaya yang dipencarkan serta dibentuk oleh panjang gelombang. Identitas suatu warna bisa ditentukan oleh panjang gelombang cahaya tersebut (Wirania, 2010). Menurut Wirania terdapat 3 jenis warna, yaitu:

\section{A. Warna Primer}

Warna Primer adalah warna yang tidak tercampur dengan warna yang lain. Merah, biru dan kuning merupakan warna yang termasuk ke dalam warna primer.

B. Warna Sekunder

Warna sekunder adalah warna yang dihasilkan melalui proses penggabungan antara dua warna primer. Warna orange diperoleh dari pencampuran antara warna kuning dan merah. Warna hijau didapatkan melalui pencampuran warna biru dengan kuning serta ungu adalah pencampuran warna merah dan biru.

C. Warna Tersier

Warna tersier adalah pencampuran warna primer dengan warna sekunder. Contohnya, warna jingga kekuningan diperoleh dari campuran kuning dan jingga. Warna biru keunguan didapat dari campuran warna biru dan ungu.

Warna yang digunakan dalam desain Game Edukasi Pengenalan Hewan Berdasarkan Cara Berkembangbiaknya ini adalah warna dominan biru karena memiliki latar dasar laut. Warna hijau untuk memberikan warna rumput laut dan warna utama dari karakter Ikan Badut yaitu merah muda, hitam dan putih.

Game merupakan hiburan yang sering digunakan untuk menyegarkan pikiran dari rasa penat yang dikarenakan oleh banyak aktivitas. Sebuah komputer tidak akan sempurna apabila tidak dilengkapi dengan game. Ungkapan tersebut menggambarkan keadaan pada saat ini. Hampir setiap komputer sudah memiliki game, baik game berukuran besar maupun kecil. Rachman (Rachman, 2012) mengatakan bahwa game edukasi merupakan aplikasi digital yang didesain untuk memberikan edukasi kepada seseorang terkait materi tertentu. Game edukasi juga dapat membantu orang lain dalam belajar suatu keterampilan sambil bermain. Materi pendidikan yang didesain ke dalam bentuk aplikasi interaktif dengan tujuan meningkatkan kecerdasan bagi pemainnya. Elemen-elemen dalam game edukasi berbasis pada konsep pendidikan dasar dan menggabungkan beberapa unsur, yaitu: bermain, mengambil keputusan, mendidik, bertualang, kreatif, motivasi, berlogika dan menyenangkan. Konsep ini disesuaikan berdasar usia pengguna serta kurikulum yang digunakan. Game edukasi merupakan permainan digital yang didesain untuk menyampaikan materi 
pembelajaran dalam dunia pendidikan dengan menggunakan teknologi multimedia interaktif.

Anik Vega Vitianingsih dalam penelitiannya menerangkan bahwa game edukasi memiliki beberapa keunggulan jika dibandingkan dengan pembelajaran metode konvensional. Beberapa keunggulan tersebut adalah terdapat animasi yang mampu meningkatkan daya ingat sehingga anak bisa menyimpan materi pelajaran dalam kurun waktu yang lebih lama dibandingkan dengan pengajaran metode konvensional.

Ridwan Arif Rahman dalam penelitianya menjelaskan bahwa terdapat beberapa masalah dalam proses penyampaian materi pelajaran kepada anak usia dini, seperti kebosanan anak ketika belajar serta sulit memahami materi pembelajaran secara konvensional. Dari penjelasan tersebut, game edukasi mampu mengatasi masalah pembelajaran dalam proses meningkatkan minat belajar, membantu berkembangnya kecerdasan dan meningkatkan kemampuan dalam proses belajar anak di usia dini.

Menurut Kebritchi \& Hirumi dalam Andri Setiawan, Henry Praherdhiono, Sulthoni, "Penggunaan Game Edukasi Digital Sebagai Sarana Pembelajaran Anak Usia Dini”, Jurnal JINOTEP Vol (6) No.1 (2019): 39, (Andri Setiawan, Henry Praherdhiono, 2019) menerangkan bahwa game edukasi digital bisa digunakan sebagai alat yang efektif dalam proses pembelajaran karena mampu memberikan motivasi serta kepuasan pribadi, mampu memberikan keterampilan belajar, dan memberikan konteks logika dalam memecahkan sebuah masalah.

Penggolongan hewan adalah bagian dari pelajaran Ilmu Pengetahuan Alam pada sekolah dasar kelas 3. Pada pelajaran makhluk hidup dan kebutuhan hidupnya para siswa diharapkan dapat memahami ciri-ciri dan kebutuhan makhluk hidup, serta hal-hal yang bisa mempengaruhi perubahan pada makhluk hidup, dan memahami penggolongan makhluk hidup secara sederhana. Hewan dapat digolongkan berdasarkan jenis makanan, tempat hidup, penutup tubuh, cara bergerak, cara bernafas, serta berdasarkan cara berkembangbiak (Tim Tunas Karya Guru, 2013).
A. Penggolongan Hewan berdasar jenis makanan

- Herbivora merupakan hewan pemakan tumbuhan yaitu Sapi, Kuda, dan Kelinci.

- Karnivora merupakan hewan pemakan daging yaitu Kucing, Singa, Serigala, dan Harimau.

- Omnivora merupakan hewan pemakan daging dan tumbuhan yaitu Tikus dan Ayam.

B. Penggolongan Hewan berdasarkan tempat hidup

- Hewan hidup di darat, yaitu Kambing, Kuda dan Kelinci.

- Hewan hidup di air, yaitu Ikan, cumicumi, kepiting.

- Hewan hidup di darat dan air, yaitu hewan amfibi (Amphibia) merupakan hewan bertulang belakang dan bisa hidup di dua alam. Contohnya adalah Katak dan Kadal.

C. Penggolongan Hewan berdasarkan cara berkembangbiak

- Ovipar, yaitu hewan berkembangbiak dengan cara bertelur. Contohnya itik, ayam, ikan, bebek.

- Vivipar, yaitu hewan berkembangbiak dengan cara melahirkan atau beranak. Contohnya kerbau, kambing, kuda, gajah, kucing, kelinci, dan tikus.

Ovovivipar, yaitu hewan berkembangbiak dengan cara beranak dan bertelur. Contohnya kuda laut.

\section{METODE}

Dalam penelitian ini, penulis menggunakan beberapa metode untuk mengumpulkan data, yaitu:

\section{A. Observasi}

Observasi merupakan metode yang disusun secara sistematis tentang apa yang diteliti serta variabel yang diamati. Observasi yang dilakukan oleh penulis yaitu dengan mengamati game sejenis (Feeding Frenzy). Dari aplikasi tersebut bisa dikaji hal-hal apa saja yang bisa menjadi nilai tambah untuk perancangan game edukasi pengenalan hewan ini. Setelah mengamati game tersebut, didapat bahwa game tersebut bertemakan petualangan dengan mengumpulkan koin. Setiap mendapat koin maka nilai akan bertambah. Dari pengamatan tersebut, penulis ingin membuat game petualangan yang memiliki nilai tambah 
dengan memberikan materi pembelajaran tentang pengenalan hewan. Dalam game ini nilai akan bertambah jika pemain memakan hewan kecil dan berhasil menjawab setiap pertanyaan yang ada.

B. Wawancara

Wawancara adalah suatu teknik pengumpulan data atau informasi dari narasumber. Dalam proses perancangan game edukasi pengenalan hewan ini, penulis melakukan wawancara dengan pemilik PT. Bamboomedia Cipta Persada Bapak Putu Sudiarta. Bamboo Media Denpasar merupakan perusahaan yang bergerak di bidang pengembangan software, salah satunya adalah game edukasi.

C. Kepustakaan

Metode Kepustakaan adalah suatu teknik mengumpulkan data dan informasi dari berbagai sumber, seperti penelitian sebelumnya serta buku yang memuat kajian teori yang dibutuhkan oleh penulis. Dalam metode kepustakaan ini penulis mengumpulkan sumber bacaan dan artikel yang berkaitan dengan game edukasi.

\section{Konsep Perancangan}

Konsep dari game edukasi pengenalan hewan yang dirancang adalah petualangan yang dilakukan oleh ikan Badut di dasar laut. Pemilihan karakter ikan adalah untuk menyesuaikan dengan konsep petualangan di laut. Konsep petualangan dipilih karena game ini akan mengajak pemainnya seolah-olah bertualang di dasar laut. Jenis game edukasi ini adalah arcade game dan adventure game. Dengan sistem leveling diharapkan membuat anak-anak terpacu untuk menyelesaikan setiap level dalam game. Perancang berusaha untuk dapat menyajikan rancangan game yang mampu mempengaruhi sasaran dengan pedoman pada dasar perancangan interaktif multimedia, dapat diterima bukan hanya menghibur dan menambah pengetahuan bagi sasaran yang dituju.

Game edukasi yang dirancang terdiri dari 3 tingkat, yaitu level 1, level 2, level 3 dan setiap level mempunyai tingkat kesulitan berbeda. Pada setiap level, ikan Badut akan berpetualang sambil memakan ikan-ikan kecil dan menghindari sampah yang lewat. Ketika sudah menemukan bintang laut, maka pemain akan disuguhkan dengan 3 pertanyaan tentang hewan sesuai dengan perkembangbiakannya.

\section{Alur Penelitian}

Proses perancangan game edukasi pengenalan hewan dimulai dari faktor internal dan eksternal seperti pada gambar 2 di bawah. Faktor internal adalah adanya keinginan untuk memberikan alternatif belajar berupa game edukasi kepada anak-anak usia dini. Faktor eksternal adalah dampak negatif yang ditimbulkan oleh game karena banyak mengandung kekerasan di dalamnya. Dari kedua faktor tersebut, penulis menentukan ide untuk meminimalisir dampak negatif dengan merancang sebuah media interaktif berupa game edukasi. Tahap berikutnya adalah merumuskan masalah, mengumpulkan data, dan membuat konsep. Data yang dikumpulkan yaitu melalui proses dokumentasi, wawancara dan kepustakaan. Konsep dari game ini adalah petualangan di laut. Setelah itu, dilanjutkan dengan proses pembuatan storyboard, desain menu, aset karakter dan aset background. Kemudian dilanjutkan dengan pascaproduksi yaitu menghasilkan media game edukasi. Pada tahap pascaproduksi, game tersebut dikonversi menjadi bentuk exe yang siap dimainkan dalam komputer.

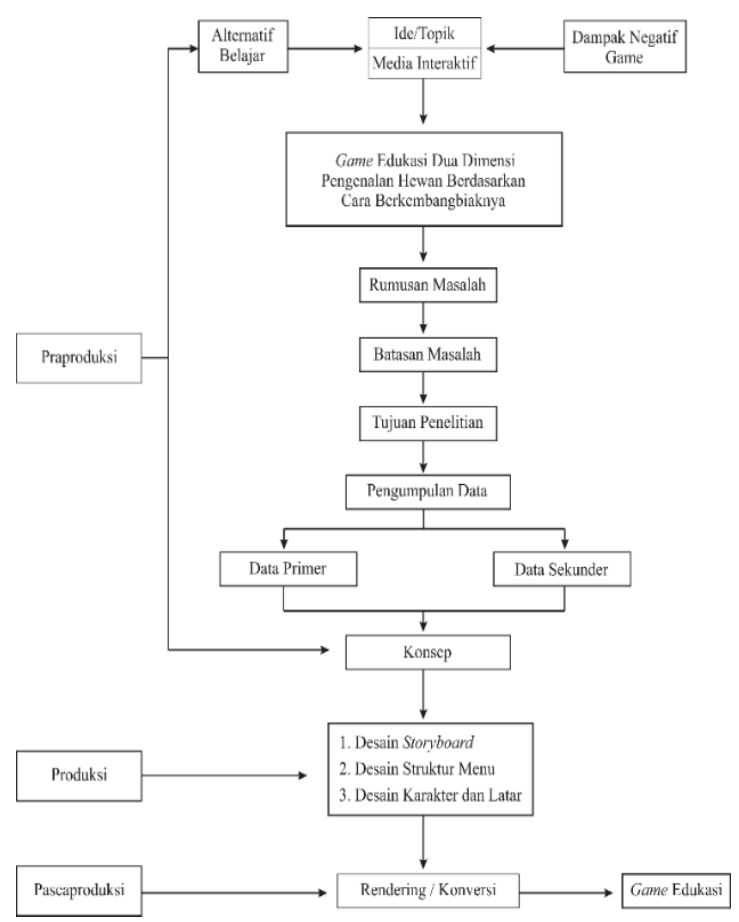

Gambar 2. Alur Penelitian [Sumber: Darma Yasa, Ngakan 2020] 


\section{HASIL DAN PEMBAHASAN Konsep Desain}

Konsep desain dalam game ini adalah ilustrasi kartun vektor sederhana. Dengan ilustrasi kartun vektor, gambar yang dihasilkan akan terlihat lebih jelas dan kartun memiliki kesan lucu, sederhana serta menarik sehingga mudah untuk dikenali oleh anak-anak. Warna yang digunakan menyesuaikan dengan latar yang digunakan yaitu dasar laut.

\section{Storyboard dan Ilustrasi dalam Game}

Storyboard merupakan sebuah konsep yang dituangkan ke dalam bentuk visual disertai penjelasan sebagai acuan untuk penulis dalam menyelesaikan sebuah karya dengan baik dan benar. Storyboard mempunyai peran penting dalam mengembangkan aplikasi multimedia agar sesuai dengan ide yang sudah direncanakan sebelumnya. Dalam proses perancangan game edukasi, penulis menggunakan storyboard sebagai panduan dalam menentukan isi yang ditampilkan pada setiap rancangan game. Berikut penjelasan tampilan dari storyboard Game Edukasi Pengenalan Hewan Berdasarkan Cara Berkembangbiaknya.
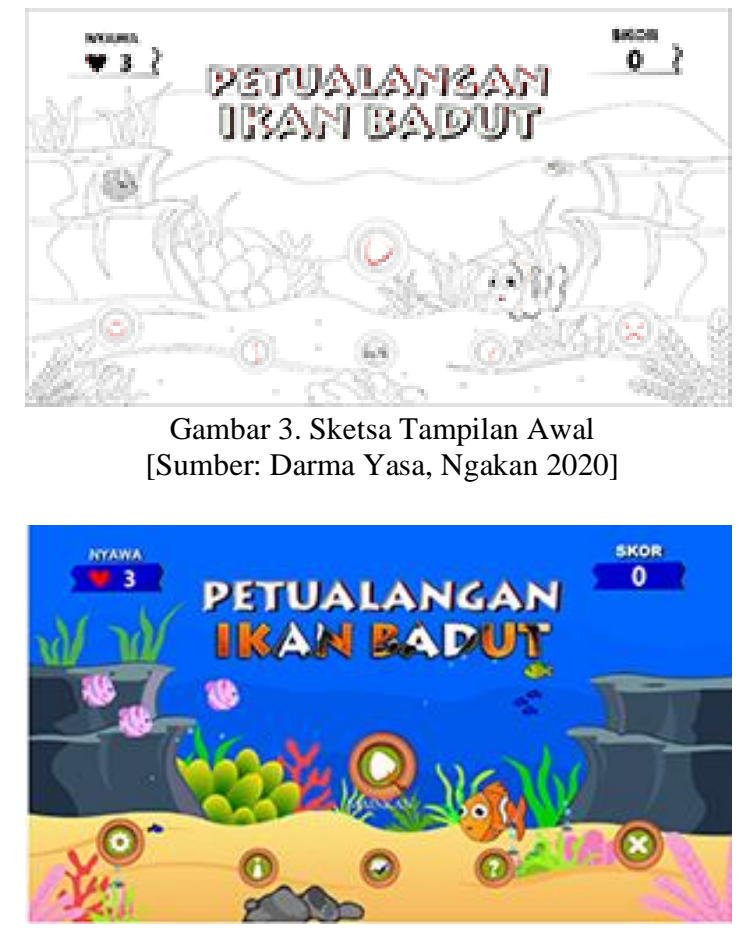

Gambar 4. Ilustrasi dalam Game [Sumber: Darma Yasa, Ngakan 2020]
Tampilan awal game berisi ilustrasi dasar laut, animasi ikan yang bergerak, menampilkan tombol-tombol yang digunakan untuk mengontrol permainan. Pada tampilan awal game terdapat 5 tombol utama yaitu "Mainkan", "Pengaturan", "Info", "Belajar", "Petunjuk", "Keluar".

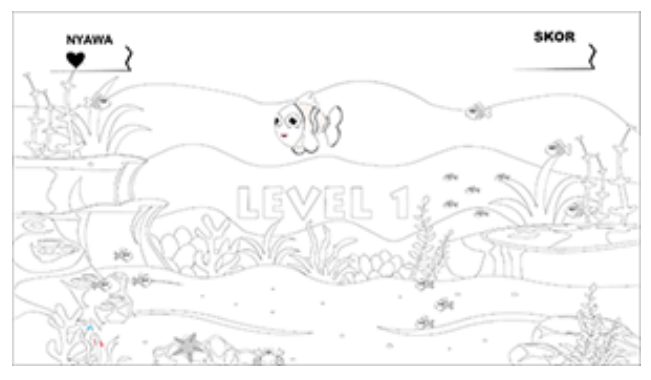

Gambar 5. Sketsa Level 1

[Sumber: Darma Yasa, Ngakan 2020]

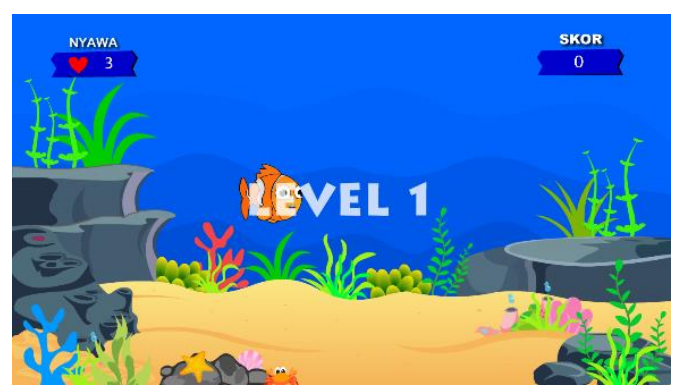

Gambar 6. Ilustrasi dalam Game

[Sumber: Darma Yasa, Ngakan 2020]

Tampilan ketika pemain memilih tombol "Mainkan". Pemain akan langsung diarahkan ke level 1.

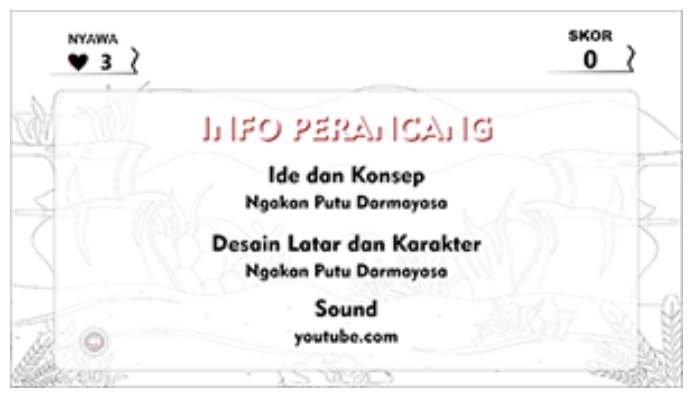

Gambar 7. Sketsa Info Perancang [Sumber: Darma Yasa, Ngakan 2020] 


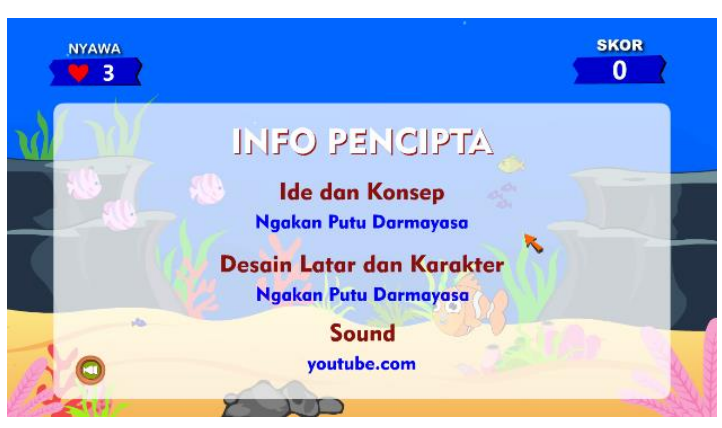

Gambar 8. Ilustrasi dalam Game [Sumber: Darma Yasa, Ngakan 2020]

Tampilan ketika pemain memilih tombol "Info" yang menampilkan informasi tentang perancang game.

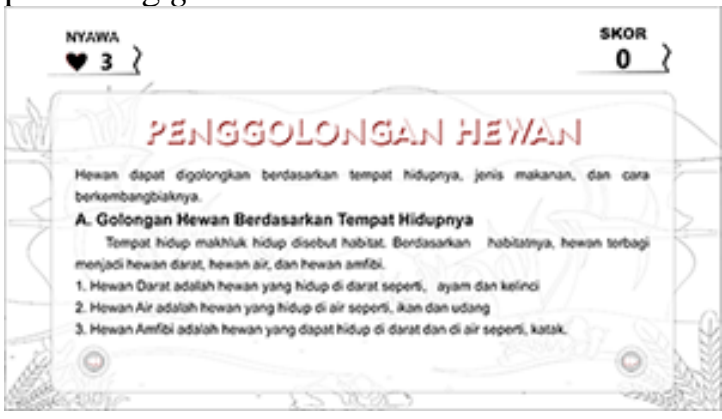

Gambar 9. Sketsa Materi Belajar [Sumber: Darma Yasa, Ngakan 2020]

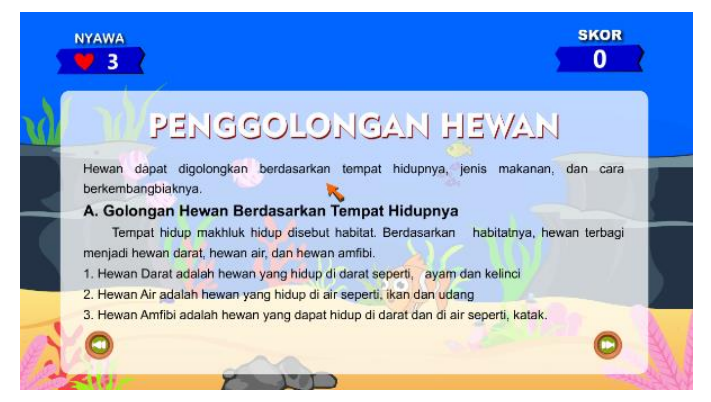

Gambar 10. Ilustrasi dalam Game [Sumber: Darma Yasa, Ngakan 2020]

Tampilan ketika pemain memilih tombol "Belajar" yang menampilkan materi yang dipelajari pada game.

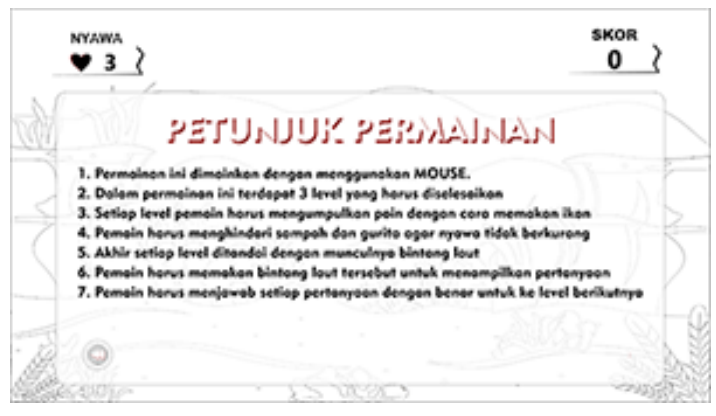

Gambar 11. Sketsa Petunjuk Permainan

[Sumber: Darma Yasa, Ngakan 2020]

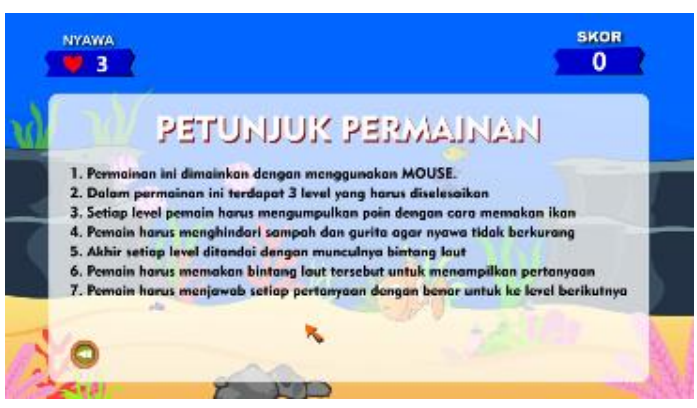

Gambar 12. Ilustrasi dalam Game

[Sumber: Darma Yasa, Ngakan 2020]

Tampilan ketika pemain memilih tombol "Petunjuk" yang menampilkan cara memainkan game.

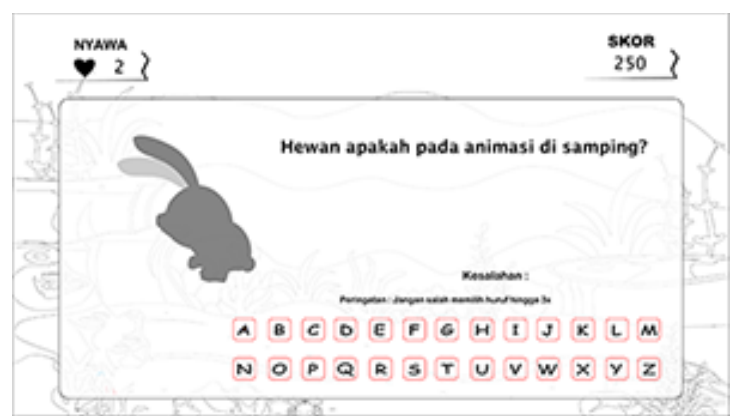

Gambar 13. Sketsa Pertanyaan

[Sumber: Darma Yasa, Ngakan 2020]

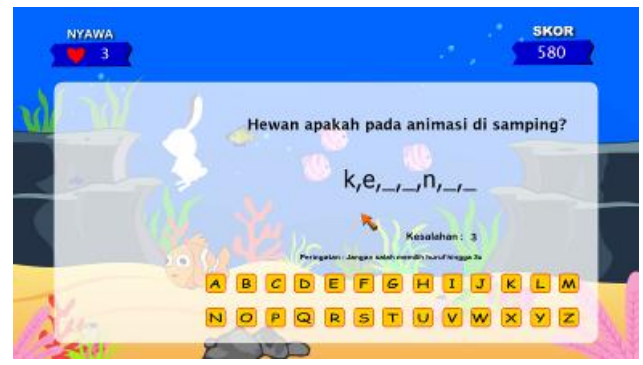

Gambar 14. Ilustrasi dalam Game

[Sumber: Darma Yasa, Ngakan 2020] 
Tampilan pertanyaan yang akan ditemukan oleh pemain ketika berhasil melewati setiap level yang dimainkan.

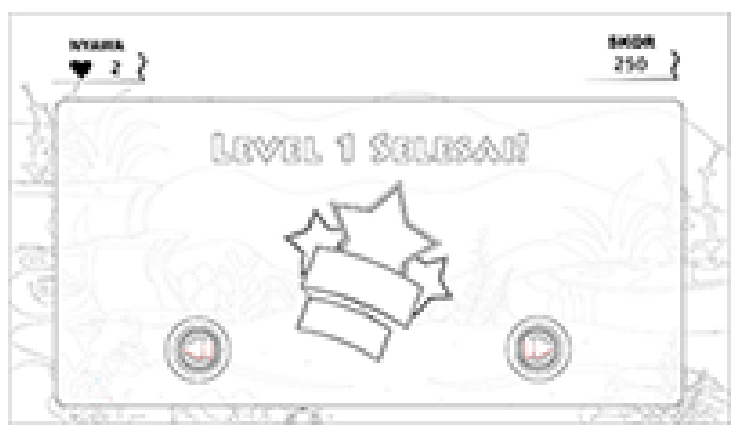

Gambar 15. Sketsa Level 1 Selesai [Sumber: Darma Yasa, Ngakan 2020]

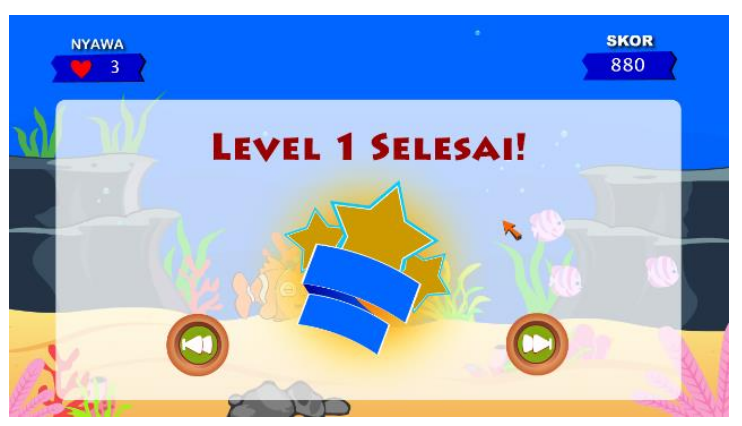

Gambar 16. Ilustrasi dalam Game [Sumber: Darma Yasa, Ngakan 2020]

Tampilan ketika pemain bisa menyelesaikan pertanyaan yang disuguhkan dalam game.

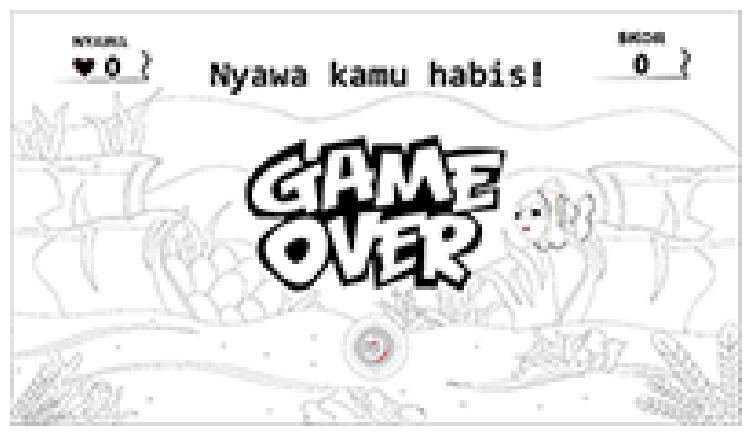

Gambar 17. Sketsa Game Over [Sumber: Darma Yasa, Ngakan 2020]

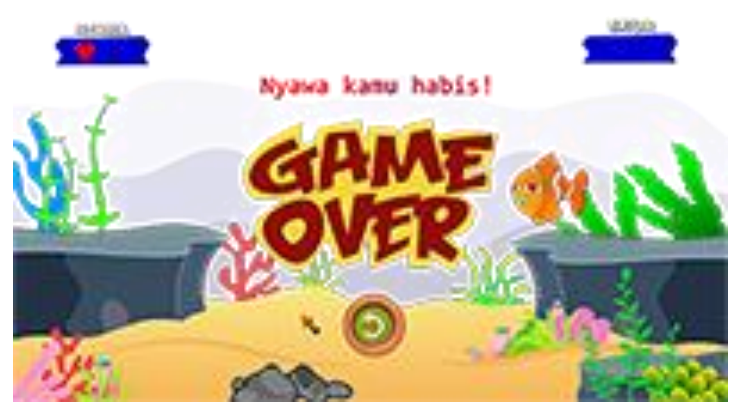

Gambar 18. Ilustrasi dalam Game

[Sumber: Darma Yasa, Ngakan 2020]

Tampilan ketika pemain kehabisan nyawa karena menyentuh sampah yang lewat atau pemain salah memilih huruf dalam menjawab pertanyaan sampai 3 kali kesempatan.

\section{Pengujian Aplikasi}

Jayanegara I Nyoman, Adi Putra Yasa I Wayan, Perancangan Game Jalak Bali Berbasis Android, Jurnal JANAPATI Vol. 4 No. 1 Maret 2015, ISSN 2087-2658, hal: 29 (Jayanegara I Nyoman, 2015) melakukan pengujian sendiri dengan memperhatikan fungsi button yang ada pada setiap tampilan game yang dirancang.

Pada tahap pengujian game edukasi pengenalan hewan ini, penulis juga melakukan pengujian sendiri terhadap fungsi button yang ada pada setiap tampilan game. Pengujian secara langsung akan dilakukan jika sekolah sudah dibuka. Pada game ini terdapat tampilan intro, tampilan level 1 , level 2 , level 3 , tampilan menjawab pertanyaan, tampilan ketika berhasil menjawab pertanyaan dan tampilan game over. Pada masing-masing tampilan terdapat button yang saling berhubungan dengan tampilan yang lainnya. Hasil dari pengujian yang dilakukan penulis bisa dilihat pada tabel $1 \mathrm{di}$ bawah.

Tabel 1. Hasil Pengujian Aplikasi

[Sumber: Darma Yasa, Ngakan, 2020]

\begin{tabular}{|c|l|l|c|c|}
\hline \multirow{2}{*}{ No. } & \multirow{2}{*}{ Tampilan } & \multicolumn{1}{|c|}{ Button } & \multicolumn{2}{c|}{ Berfungsi } \\
\cline { 4 - 5 } & & Ya & Tidak \\
\hline 1 & Intro & $\begin{array}{l}\text { a. Mainkan } \\
\text { b. Pengaturan } \\
\text { c. Info }\end{array}$ & $\sqrt{ }$ & \\
\hline
\end{tabular}




\begin{tabular}{|c|l|l|c|l|}
\hline & & $\begin{array}{l}\text { d. Belajar } \\
\text { e. Petunjuk } \\
\text { f. Keluar }\end{array}$ & & \\
\hline 2 & Pengaturan & $\begin{array}{l}\text { a. Kembali } \\
\text { b. Sound } \\
\text { c. Layar }\end{array}$ & $\sqrt{ }$ & \\
\hline 3 & Info & Kembali & $\sqrt{ }$ & \\
\hline 4 & Belajar & $\begin{array}{l}\text { a. Kembali } \\
\text { b. Next }\end{array}$ & $\sqrt{ }$ & \\
\hline 5 & Petunjuk & Kembali & $\sqrt{ }$ & \\
\hline 6 & Keluar & Keluar & $\sqrt{ }$ & \\
\hline
\end{tabular}

\section{SIMPULAN DAN SARAN}

Hasil dari penelitian ini adalah Game Edukasi Pengenalan Hewan untuk anak usia dini yaitu kelas 3 Sekolah Dasar. Game edukasi ini bisa dimainkan pada semua jenis laptop karena sudah berbasis desktop. Dalam merancang game Edukasi Pengenalan Hewan terdapat tahapan-tahapan yang harus dilewati mulai dari menentukan ide, mengumpulkan informasi, menentukan konsep perancangan, pembuatan desain, animasi dan mengkoding.

Materi pembelajaran yang diambil dari buku kelas 3 Sekolah Dasar membuat anakanak mempunyai alternatif untuk belajar melalui sebuah media digital. Materi pengenalan hewan tersebut divisualisasikan dengan gambar vektor dan gaya kartun ke dalam bentuk game edukasi.

Pada proses pengujian game yang dilakukan oleh peneliti, bahwa button pada aplikasi sudah berfungsi dengan baik sesuai perancangan yang ditentukan dari awal. Selanjutnya jika sekolah sudah dibuka kembali, maka aplikasi ini akan diujikan langsung.

Sebelum merancang sebuah game edukasi sebaiknya ditentukan terlebih dahulu materi yang ingin ditampilkan dalam game dan disesuaikan dengan kebutuhan anak. Pada proses perancangan digital dengan menggunakan software Adobe Flash disarankan untuk menggunakan gambar vektor agar gampang diedit ketika terjadi kesalahan gambar. Pembuatan animasi dalam game sebaiknya memperhatikan prinsip-prinsip dasar animasi agar pergerakan animasi tidak bosan untuk dilihat.

Untuk pengembangan lebih lanjut, game edukasi ini bisa dikembangkan dalam bentuk aplikasi android agar publikasinya lebih praktis lewat Play Store.

\section{DAFTAR PUSTAKA}

Suryana, D. (2016). Pendidikan Anak Usia Dini : stimulasi dan aspek perkembangan Anak. Kencana.

Henry, S. (2010). Cerdas dengan Game. PT. Gramedia.

Habibu Rahman, R. K. (2020). No TitlePengembangan Nilai Moral dan Agama Anak Usia Dini. Edu Publisher.

Anik Vega Vitianingsih. (2016). Game Edukasi Sebagai Media Pembelajaran Pendidikan Anak Usia Dini. Jurnal INFORM, Vol. 1, 25.

Putra, D. W. (2016). Game Edukasi Berbasis Android Sebagai Media Pembelajaran Untuk Anak Usia Dini. Jurnal Informatika Merdeka Pasuruan, 1 .

Sari, P. I. (2015). Game Edukasi Mata Pelajaran Ilmu Pengetahuan Alam (IPA) Dan Ilmu Pengetahuan Sosial (IPS) Pada Sekolah Dasar Negeri Sooka I Punung Kabupaten Pacitan. Journal Speed Sentra Penelitian Engineering Dan Edukasi, 7.

Ridwan Arif Rahman, D. T. (2016). Pengembangan Game Edukasi Pengenalan Nama Hewan dan Habitatnya Dalam 3 Bahasa Sebagai Media Pembelajaran Berbasis Multimedia. Jurnal Algoritma Sekolah Tinggi Teknologi Garut, Vol. 13, 184.

Limbong, Toni \& Simarmata, J. (2020). Media dan Multimedia Pembelajaran: Teori \& Praktik. Yayasan Kita Menulis.

Binanto, I. (2010). Multimedia Digital - Dasar Teori dan Pengembangannya. In C.V Andi Offset. Andi Offset.

Wirania, S. (2010). A-Z Warna Interior Rumah 
Tinggal. Griya Kreasi.

Rachman, S. (2012). Perancangan Mobile Game Edukatif "Mewarnai Gambar" Dengan Adobe Flash Cs5. Repository.Amikom.Ac.Id.

Andri Setiawan, Henry Praherdhiono, S. (2019). Penggunaan Game Edukasi Digital Sebagai Sarana Pembelajaran Anak Usia Dini. Jurnal Inovasi Teknologi Pembelajaran, Vol 6, 41.

Tim Tunas Karya Guru. (2013). Kreatif Ilmu Pengetahuan Alam Kelas 3 untuk Sekolah Dasar. Duta.

Jayanegara I Nyoman, A. P. Y. I. W. (2015). Perancangan Game Jalak Bali Berbasis Android. Jurnal Nasional Pendidikan Teknik Informatika (JANAPATI), Vol. 4, 29. 